\title{
Millennial Tourists in Bali: Motivation, Satisfaction and Revisit Intention
}

\section{Dewa Ayu Nyoman Aridayanti ${ }^{1}$, I Gusti Ayu Oka Suryawardani ${ }^{2}$ and Agung Suryawan Wiranatha ${ }^{2}$}

\author{
${ }^{1}$ Agribusiness Study Program, Faculty of Agriculture, Udayana University \\ ${ }^{2}$ Centre of Excellence in Tourism, Udayana University
}

Corresponding Author: dewaayuaridayanti@gmail.com

\begin{abstract}
ARTICLE INFO
Received

30 November 2019

Accepted

30 January 2020

Available online

01 March 2020

The Ministry of Tourism of the Republic of Indonesia has developed strategies to attract millennial tourists who are estimated to dominate the world tourism market, where Bali is ranked as the fourth most desirable destination for millennials around the world. One of the important factors for tourists in making a visit decision is motivation. Motivation can affect tourists' satisfaction that is triggered by evaluations through their experiences during a visit and it can affect their revisit intention. Decision making for revisit intention to a destination is actually the behavior of satisfied tourists. This research is a quantitative study with samples of millennial tourists visiting the areas of Ubud, Kuta, Seminyak, Canggu and Uluwatu. Research results were analyzed by Structural Equations Modelling (SEM) analysis usings SmartPLS software 3.0 version. The results showed that motivation consisting of push and pull factors has a significant effect on tourist satisfaction. Tourist satisfaction has a significant effect on the revisit intention. The push factor has a positive but not significant effect on the revisit intention while the pull factor has a significant effect on the revisit intention. Another result showed that $69 \%$ of millennial tourists make use of social media as a source of information about Bali. This is also the reason for the facts that $91 \%$ of millennial tourists prefer to arrange their own trips.
\end{abstract}

Keywords: Bali, motivation, satisfaction, revisit intention, millennial tourist.

\section{INTRODUCTION}

By the rapidly developing tourism industry, world tourism destinations face stiff competition which makes the destination must be able to win the competition in order to be chosen by the majority of tourists. Bali is one of the destinations that can compete with other destinations in the world, and Bali achieves several awards every year. In 2019, Bali was ranked fourth in the world e-ISSN: 2407-392X. p-ISSN: 2541-0857 
as the most popular destination for millennial around the world by the Hopper ticket booking application company. This list is obtained from the most popular, the most searched for, and the most monitored destination data by millennial tourists. In line with the Republic of Indonesia's Ministry of Tourism strategies to attract millennial tourists, Bali's ranking has opened up opportunities for Indonesia to target the Millennial Market. Millennial generation is driving big changes in the travel industry. Millennials are more likely to travel than other generations and tend to be motivated by the desire to adventure and explore something new. The tour process begins with the motivation that plays a role in making decisions about the destination to be visited. Push and pull factors in motivation may affect tourist satisfaction. Motivation triggers every evaluation that tourists can do about a destination through their experiences during their visit. The decision to make a repeat visit to a destination is a result of satisfied tourist behavior.

\section{LITERATURE REVIEW}

This research reviewed 14 previous studies as references sourced from national and international journals that have a common topic with tourist motivation, tourist satisfaction, revisit intention and http://ojs.unud.ac.id/index.php/eot millennial tourists or travelers. The studies include (1) The Effect of Travel Motivation on Satisfaction: The Case of Older Tourist by Vigolo, et.al (2018); (2) The Effect of Motivation, Satisfaction and Perceived Value on Tourist Recommendation by Huang, et.al (2015); (3) Travel Motives, Perceptions and Satisfaction of Millennial Travelers: A Study in the East Coast of Sri Lanka by Gnanapala, et.al (2017).

Research by Vigolo, et.al (2018) investigate the effect of tourist travel motivation on satisfaction; Huang, et.al (2015) analyze the effect of motivation, satisfaction and perceived value on tourist recommendations; and Gnanapala, et.al (2017) explore travel motivations, perceptions, satisfaction, and other behavioral characteristics of millennial tourists visiting the East Coast of Sri Lanka.

The research resulted in several findings including: (1) Vigolo, et.al (2018) found that motivation influences satisfaction but varies greatly depending on the age of the respondent; (2) Huang, et.al (2015) found that there was an influence of the three (motivation, satisfaction and perceived value) on tourist recommendations. The effect of perceived value and satisfaction on recommendations is greater than motivation. Motivation can be a predictor of recommendations; (3) Gnanapala, et.al (2017) research findings 
show that push and pull factors motivate millennial tourists to visit the remote areas of Sri Lanka. Whereas tourist satisfaction is influenced by accommodation, infrastructure, service quality and tourist attractions.

This research refers to theories of tourism, generation, and tourist behavior and the concepts of motivation, satisfaction and revisit intention.

\section{RESEARCH METHODS}

Research was conducted to analyze and test causal relationships between constructs or latent variables. The cause of causal relationships is called exogenous latent constructs or variables $\mathrm{X}$ which consists of Push Factors as (X1) and Pull Factors as (X2), while the constructs that are affected are called endogenous latent namely $\mathrm{Y}$ variable consisting of Tourist Satisfaction (Y1) and Revisit Intention (Y2). To analyze and test the causal relationship between variables, a partial least square (PLS) statistical analysis tool was used, i.e. one of the structural equation modeling (SEM) statistical methods or variant-based structural equation models with smart PLS version 3.0 software.

The research population was millennial tourists coming to Bali, taken using cluster random sampling techniques http://ojs.unud.ac.id/index.php/eot in the areas of Ubud, Kuta, Seminyak, Canggu and Uluwatu of 100 millennial tourists respondents with a quota sampling of 50 foreign tourists and 50 domestic tourists. The number of samples is in accordance with the number of sample eligibility criteria for a variant-based or Partial Least Square (PLS) Structural Equation Modeling (SEM) analysis, which is a minimum of 30 and a maximum of 100 samples. In addition to using structural equation modeling (SEM) analysis with SmartPLS software version 3.0, the research findings were also analyzed descriptively and qualitatively to describe the characteristics of respondents, interpret the SEM analysis results and the results of hypothesis testing.

In the analysis of PLS-SEM (Partial Least Square-Structural Equation Modeling) the validity and reliability tests were carried out by focusing a few. In the validity test conducted with convergent validity criteria with outer loading value> 0.5 and discriminant validity with AVE value> 0.5. While reliability is indicated by Cronbach's Alpha value> 0.6 and composite reliability value $>0.6$.

The structural equation model consists of measurement and structural models. Measurement model aims to determine the role of indicators in reflecting variables, while the structural model aims to examine the relationship 
between other variables, both direct and indirect relationships and total effects. Later, after analyzing the data a structural equation model will be generated which will be evaluated both from the Measurement model and the Structural model. Evaluation of the Measurement model is done to assess the validity and reliability of the model, while the structural model or structural model evaluation is to evaluate the value of $\mathrm{R}^{2}$, Effect size, and GoF (Goodness of FIT).

\section{RESULTS AND DISCUSSION}

\section{Tourist Characteristics}

The results show several characteristics of millennial tourists coming to Bali, including: 1) $64 \%$ of millennial tourists were dominated by female tourists; 2) $44 \%$ of millennial tourists came from Europe with allocentric type; 3) $59 \%$ of millennial tourists are students; 4) $97 \%$ of the purpose of visiting is for a vacation; 5) $50 \%$ of visits with friends; 6) $69 \%$ used social media as a source of information about Bali; 7) 91\% arrange their own visits.

\section{Influence between Variables}

Confirmative analysis in this research is intended to draw inference related to the influence of push and pull factors on satisfaction and revisit intention. http://ojs.unud.ac.id/index.php/eot
Therefore, this research model involves 4 (four) latent variables, namely the push factor variable is reflected through 6 (six) indicators, the pull factor variable is reflected by 5 (five) indicators, the satisfaction variable is reflected by 6 (six) indicators and the revisit intention variable reflected by 5 (five) indicators. The structural equation model that is performed after going through the bootstrapping process can be seen in Figure 1 below.

\section{Measurement model (outer model)}

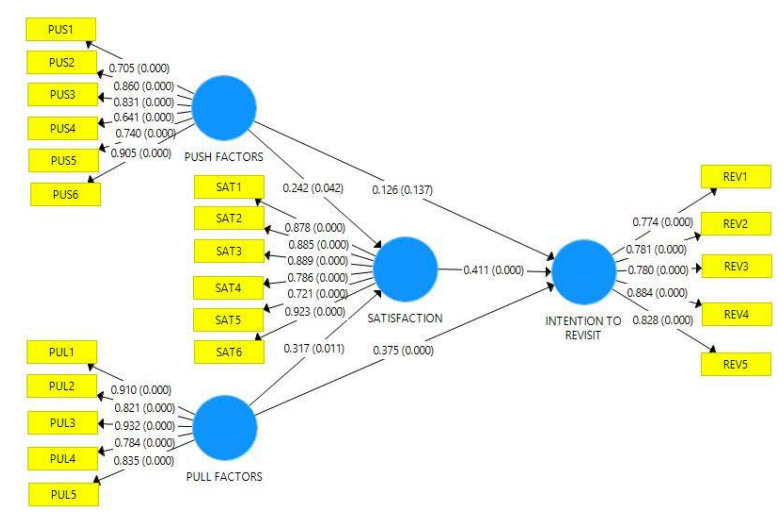

Source: Smart PLS Analysis Output 3.0, 2019.

Figure 1. Structural Output Model

Testing the validity of the research variables was conducted by convergent validity and discriminant validity with the outer loading and AVE criteria> 0.5. The results of the validity test can be seen in Table 1. 
Table 1

Research Variable Validity Test

Results

\begin{tabular}{|c|c|c|c|c|}
\hline \multirow[b]{2}{*}{ Variable } & \multirow[b]{2}{*}{$\begin{array}{l}\text { Indica } \\
\text { tor }\end{array}$} & \multicolumn{3}{|c|}{ Validity } \\
\hline & & $\begin{array}{l}\text { Converg } \\
\text { ent }\end{array}$ & $\begin{array}{l}\text { Discriminant } / \sqrt{ } \mathrm{A} \\
\mathrm{VE}\end{array}$ & AVE \\
\hline \multirow{6}{*}{$\begin{array}{l}\text { Push } \\
\text { Factors }\end{array}$} & PUS1 & 0.705 & \multirow{6}{*}{0.786} & \multirow{6}{*}{0.617} \\
\hline & PUS2 & 0.860 & & \\
\hline & PUS3 & 0.831 & & \\
\hline & PUS4 & 0.641 & & \\
\hline & PUS5 & 0.740 & & \\
\hline & PUS6 & 0.905 & & \\
\hline \multirow{5}{*}{ Pull Factors } & PUL1 & 0.910 & \multirow{5}{*}{0.858} & \multirow{5}{*}{0.736} \\
\hline & PUL2 & 0.821 & & \\
\hline & PUL3 & 0.932 & & \\
\hline & PUL4 & 0.784 & & \\
\hline & PUL5 & 0.835 & & \\
\hline \multirow{6}{*}{ Satisfaction } & SAT1 & 0.878 & \multirow{6}{*}{0.811} & \multirow{6}{*}{0.722} \\
\hline & SAT2 & 0.885 & & \\
\hline & SAT3 & 0.889 & & \\
\hline & SAT4 & 0.786 & & \\
\hline & SAT5 & 0.721 & & \\
\hline & SAT6 & 0.923 & & \\
\hline \multirow{5}{*}{$\begin{array}{l}\text { Revisit } \\
\text { Intention }\end{array}$} & REV1 & 0.774 & \multirow{5}{*}{0.850} & \multirow{5}{*}{0.657} \\
\hline & REV2 & 0.781 & & \\
\hline & REV3 & 0.780 & & \\
\hline & REV4 & 0.884 & & \\
\hline & REV5 & 0.828 & & \\
\hline
\end{tabular}

It can be seen in Table 1 that all indicators have an outer loading value and AVE $>0.5$ thus, that all indicators are said to be valid.

Table 2

Research Variability Test Results

\begin{tabular}{lll}
\hline \multirow{2}{*}{ Variable } & \multicolumn{2}{c}{ Reliability } \\
\cline { 2 - 3 } & $\begin{array}{l}\text { Cronbach's } \\
\text { Alpha }\end{array}$ & $\begin{array}{l}\text { Composite } \\
\text { Reliability }\end{array}$ \\
\hline Push Factors & 0.878 & 0.905 \\
\hline Pull Factors & 0.909 & 0.933 \\
\hline Satisfaction & 0.921 & 0.939 \\
\hline Revisit Intention & 0.869 & 0.905 \\
\hline
\end{tabular}

Table 2 shows that all variables meet the reliable criteria because they have Cronbach's Alpha and Composite Reliability values above 0.6.

\section{Structural model (inner model)}

The structural model was evaluated using R-square for endogenous latent variables, $\mathrm{F}^{2}$ (effect size) and estimated path coefficients (Ghozali, 2014). The results of the evaluation of the three criteria are as follows:

Table 3

Value of Effect Size for Research Variables

\begin{tabular}{|c|c|c|c|c|}
\hline & PULL & PUSH & REV & SAT \\
\hline PULL & & & 0.220 & 0.103 \\
\hline PUSH & & & 0.026 & 0.060 \\
\hline \multicolumn{5}{|l|}{ REV } \\
\hline SAT & & & 0.283 & \\
\hline
\end{tabular}

The value of the effect size of the push factors on the tourist revisit intention is 0.026 with a small influence category of the latent predictor variable, while the value of the effect size of the pull factors on the tourist revisit intention of 0.22 is categorized as the medium influence of the latent variable predictor. The effect size value of tourist satisfaction with revisit intention is 0.283 that is considered as the medium influence of the latent variable predictor. 
Table 4

Statistical Value of Feasibility of Research Variables

\begin{tabular}{clccc}
\hline Variable & $\begin{array}{l}\text { Variabl } \\
\text { e Type }\end{array}$ & $\begin{array}{c}\text { Com } \\
\text { enit } \\
\text { Relia } \\
\text { bility }\end{array}$ & AVE & $\mathrm{R}^{2}$ \\
\hline Push Factor & $\begin{array}{l}\text { Exogen } \\
\text { ous }\end{array}$ & 0.905 & 0.617 & NA \\
\hline Pull Factor & $\begin{array}{l}\text { Exogen } \\
\text { ous }\end{array}$ & 0.933 & 0.736 & NA \\
\hline Satisfaction & $\begin{array}{l}\text { Exogen } \\
\text { ous/ } \\
\text { Endoge } \\
\text { nous }\end{array}$ & 0.939 & 0.722 & 0.540 \\
\hline $\begin{array}{l}\text { Revisit } \\
\text { Intention }\end{array}$ & $\begin{array}{l}\text { Endoge } \\
\text { nous }\end{array}$ & 0.905 & 0.657 & 0.229 \\
\hline & Average & & 0.683 & 0.385 \\
\hline
\end{tabular}

Source: Primary Data, 2019.

Based on Table 4, it can be explained that the satisfaction variable $R^{2}$ value is 0.540 , which indicates that the model is in the moderate category. Through this model, $54 \%$ of the variance of satisfaction variables can be explained by the push and pull factors. While the $\mathrm{R}$ square value of the revisit intention variable is 0.229, which indicates that the endogenous revisit intention model is in the weak category. The model shows that the $22.9 \%$ variance of the revisit intention variable can be explained by the tourist satisfaction variable.

The feasibility of a whole structural equation model or calculating the Goodness of Fit (GoF) value of the model can be done by referring to the formula

$$
\mathrm{GoF}=\sqrt{\text { Communality }} \times \mathrm{R}^{2}=\sqrt{\mathrm{AVE} \times \mathrm{R}^{2}}
$$

If referring to Table 4 for the above equation, $\overline{\mathrm{AVE}}$ is the weighted average value with the weight obtained from the number of indicators for each variable. Using this formula, the GoF value from the model is obtained at 0.513 that is a measure that exceeds the threshold value of 0.50 . With these calculations, the model can be accepted and interpreted.

The GoF (Goodness of Fit) test of the PLS model can also be tested through the SRMR (Standarized Roots Mean Square Residual) model value. The model will be categorized as fulfilling the GoF criteria if the SRMR value is $<0.10$ and it will be perfect fit if the SRMR value $<0.80$. The results of the GoF (Goodness of Fit) equation model are presented in Table 5 below.

Table 5

Goodness of Fit Research Model Test Results

\begin{tabular}{lrr}
\hline & Saturated Model & Estimated Model \\
\hline SRMR & 0.096 & 0.096 \\
\hline NFI & 0.589 & 0.589 \\
\hline \multicolumn{2}{l}{ Source: Primary Data, 2019. }
\end{tabular}

Based on the test results in Table 5, it can be seen that the results of the Goodness of Fit (GoF) equation model is valued at 0.096 which indicates that the model is feasible and meets the GoF value criteria. In addition to the GoF value, Table 5 also shows the value of the -ISSN: 2541-0857 
Normal Fit Index (NFI) of 0.589, which indicates that the structural model is categorized as feasible because the value has a range of values $>0.5$. Therefore, it can be concluded that the research model is feasible to use to test the research hypothesis.

Table 6

Indirect Effect of Research Variables

\begin{tabular}{|c|c|c|c|c|}
\hline $\begin{array}{c}\text { Exogenous } \\
\text { Variables -> } \\
\text { Endogenous } \\
\text { Var } \\
\end{array}$ & $\begin{array}{l}\text { Original } \\
\text { Sample }\end{array}$ & $\begin{array}{c}\text { Standard } \\
\text { of } \\
\text { Deviation }\end{array}$ & $\begin{array}{c}\mathrm{P} \\
\text { Value } \\
\mathrm{s}\end{array}$ & Sig \\
\hline $\begin{array}{l}\text { PUSH -> } \\
\text { SAT }\end{array}$ & 0.242 & 0.122 & 0.048 & $* *$ \\
\hline PULL -> SAT & 0.317 & 0.121 & 0.009 & $* *$ \\
\hline SAT -> REV & 0.411 & 0.087 & 0.000 & $* *$ \\
\hline $\begin{array}{l}\text { PUSH -> } \\
\text { REV }\end{array}$ & 0.126 & 0.088 & 0.153 & Ns \\
\hline $\begin{array}{l}\text { PULL -> } \\
\text { REV }\end{array}$ & 0.375 & 0.091 & 0.000 & $* *$ \\
\hline
\end{tabular}

Source: Primary Data (data processed), 2019.

Description:

$$
\begin{aligned}
& \text { Ns : not significant } \\
& * * \text { : significant }
\end{aligned}
$$

Based on Table 6, it can be seen that the indirect effect of exogenous variables on endogenous variables with a significance level of $5 \%$ results in that of the five direct effects, there is only one insignificant effect, namely the influence of the push factor on the revisit intention. Push and pull factors significantly influence the satisfaction of millennial tourists who come to Bali with $\mathrm{p}$ value $<0.05$ and the original sample value is positive. This indicates that the push and pull factors of millennial tourists to visit http://ojs.unud.ac.id/index.php/eot
Bali are in line with the tourists' expectations. Significant influence is shown by the satisfaction variable on revisit intention with the original sample value of 0.411 and $p$ value of 0.000 . Previous travel experience will affect the attitude of tourists to revisit to a destination. If on a previous visit tourists were satisfied, then the tourists would intend to revisit and vice versa.

This research supports the findings of Vigolo, et.al (2018), Gnapala (2017), Wiranatha (2018), Sultan (2012), Dayaour (2015), Baniya (2017), Khuong, et.al. (2014).

\section{Table 7}

\begin{tabular}{|c|c|c|c|c|}
\hline $\begin{array}{c}\text { Exogenous } \\
\text { Variables -> } \\
\text { Mediation -> } \\
\text { Endogenous }\end{array}$ & $\begin{array}{l}\text { Original } \\
\text { Sample }\end{array}$ & $\begin{array}{l}\text { Standard } \\
\text { of } \\
\text { Deviation }\end{array}$ & $\begin{array}{c}\text { P } \\
\text { Valu } \\
\text { es }\end{array}$ & Sig \\
\hline $\begin{array}{l}\text { PUSH -> } \\
\text { SAT -> REV }\end{array}$ & 0.099 & 0.063 & 0.114 & Ns \\
\hline $\begin{array}{l}\text { PULL -> SAT } \\
->\text { REV }\end{array}$ & 0.13 & 0.053 & 0.015 & $* *$ \\
\hline \multicolumn{5}{|c|}{ Source: Primary Data (data processed), 2019.} \\
\hline $\begin{array}{l}\text { Description: } \\
\text { Ns : not } \\
* * \text { : signi }\end{array}$ & $\begin{array}{l}\text { nificant } \\
\text { cant }\end{array}$ & & & \\
\hline
\end{tabular}

Indirect Effect of Research Variables

The indirect effect is the influence of exogenous variables on endogenous variables which are correlated through mediating variables. The indirect effects of this research are 1) the effect of push factors on revisit intention through satisfaction mediation; 2) the influence of pull factors on revisit intention through e-ISSN: 2407-392X. p-ISSN: 2541-0857 
satisfaction mediation. The results of the significance of the indirect effect test show that push factors do not affect the intention to revisit if mediated by satisfaction. The driving factor still does not have a significant effect on the intention to revisit directly or indirectly.

\section{Table 8}

The Total Effect of Exogenous Latent on Endogenous Latent

\begin{tabular}{lcccc}
\hline $\begin{array}{c}\text { Exogenous } \\
\text { Variations } \\
\begin{array}{l}\text { Endogenous } \\
\text { PUSH -> }\end{array}\end{array}$ & $\begin{array}{c}\text { Original } \\
\text { Sample }\end{array}$ & $\begin{array}{c}\text { Standard } \\
\text { of } \\
\text { Deviation }\end{array}$ & $\begin{array}{c}\text { P } \\
\text { Value } \\
\text { SAT }\end{array}$ & Sig \\
\hline $\begin{array}{l}\text { PULL -> } \\
\text { SAT }\end{array}$ & 0.242 & 0.122 & 0.048 & $* *$ \\
\hline $\begin{array}{l}\text { SAT -> } \\
\text { REV }\end{array}$ & 0.411 & 0.121 & 0.009 & $* *$ \\
\hline PUSH -> & 0.225 & 0.087 & 0.010 & $* *$ \\
REV & 0.505 & 0.101 & 0.000 & $* *$ \\
\hline $\begin{array}{l}\text { PULL -> } \\
\text { REV }\end{array}$ & & 0.000 & $* *$ \\
\hline
\end{tabular}

Source: Primary Data (data processed), 2019.

Description:

Ns : not significant

** : significant

Total influence is formed from a combination of direct and indirect influences. The total effect test results presented in Table 8 can be seen that all influences are positive and significant.

\section{CLOSING}

\section{Conclusion}

Push and pull factors have a significant effect on the satisfaction of millennial tourists visiting Bali. Tourist satisfaction has a significant effect on revisit intention. The push factor does not have a significant effect on the revisit intention of millennial tourists to Bali even though it is mediated by satisfaction, while the pull factor has a significant effect on revisit intention.

\section{Suggestion}

Seeing the important role of social media in the journey of millennial tourists, it is suggested that the government through the Bali Provincial Tourism Office should collaborate with experts in the field of digital marketing to create an informative social media account that contains interesting content and is able to provide complete information related to all attractions tours in Bali to attract millennial tourists visiting Bali. Improvement of destination quality must be done so that it is not monotonous, because millennial tourists have the characteristics of exploring something new. 


\section{Acknowledgments}

The author would like to thank Dr.

Ir. I Gusti Ayu Oka Suryawardani, M.Mgt., Ph.D as the first supervisor as well as the Coordinator of the Tourism Study Program at Udayana University who, with full attention and patience, gave me encouragement, enthusiasm and guidance in completing this thesis. I also thank Ir. Anak Agung Putu Agung Suryawan Wiranatha, M.Sc., Ph.D as the second supervisor with full attention and patience has provided guidance and suggestions to me. I also thank Prof. Dr. Ir. Syamsul Alam Paturusi, MSP as an academic supervisor and thesis examiner for the opportunities and guidance provided during lectures to date. I also thank Dr. I Nyoman Sudiarta, SE., M.Par and Dr. I Ketut Surya Diarta, SP., MA as the examiners who provide many inputs, suggestions and corrections so that this thesis can be completed. Thank you also to all the lecturers in the Tourism Study Program at Udayana University who have provided a lot of knowledge, insight and guidance as well as administrative staff who have helped the writer while attending lectures. Thank you to my beloved family who never stopped encouraging me to complete my master's program.

\section{REFERENCES}

Vigolo, V., F. Simeoni., F. Cassia. And M.M. Ugolini. 2018. The Effect of Travel Motivation on Satisfaction : The Case of Older Tourist. International Journal of Business and Social Science Volume 9.

Huang,S., Y. Shen., C. Choi. 2015. The Effect of Motivation, Satisfaction and Perceived Value on Tourist Recommendation. Travel and Tourism Research Association: Advancing Tourism Research Globally

Gnanapala,W.K.A.C.,A.M.J.A.Dharmasiri and J.A.R.C. Sandaruwani. 2017. Travel Motives, Perception And Satisfaction Of Millennial Travellers: A Study In East Coast Of Sri Lanka. Proceeding $7^{\text {th }}$ International Borneo Business Conference. Page 524-536. Malaysia : Universitas Malaysia Sabah.

Ghozali, I. 2014. Structural Equation Modelling Metode Alternatif dengan Partial Least Square Aplikasi. Cetakan ke empat. Semarang : Universitas Diponegoro

Wiranatha, A.S., I.G.A.O. Suryawardani, I K.G. Bendesa. 2018. Model of Foreign tourist's Loyalty in Cultural and Heritage Tourism. Journal of Global Stochastics Analysis.

Sultan, M.A., T. Haryono, B. Haryanto, A.L. Riani. 2012. Proses Pembentukan Perilaku Niat Wisatawan Berkunjung Kembali. Jurnal Siasat Bisnis Vol 16. 
Dayaour, F., \& Adongo, C.A. 2015. Why They Go There : International Tourists' Motivation and Revisit Intention to Northern Ghana. American Journal of Tourism Management, 4 (1) : pp 7-17.

Baniya, R., Ghimire, S., \& Phuyal, S. 2017. Push and pull factors and their effect on international tourists' revisit intention to Nepal. The Gaze : Journal of Tourism and Hospitality, 8 : pp 20-39.

Khuong, M.N. \& Ha H.t.t. 2014. The Influences of Push and Pull Factors on the International Leisure Tourist Return To Ho Chi Minh City, Vietnam - Mediation Analysis of Destination Satisfaction. International Journal of Trade, Economies and Finance, 5 (6) : pp 490-496. 